\title{
Modulation of signal strength switches Notch from an inducer of T cells to an inducer of ILC2
}

\author{
Rebecca Gentek ${ }^{1}$, J. Marius Munneke ${ }^{1,2}$, Christina Helbig ${ }^{1}$, Bianca Blom ${ }^{1}$, Mette D. Hazenberg ${ }^{2}$, \\ Hergen Spits ${ }^{3}$ and Derk Amsen ${ }^{1,4}$ *
}

\author{
1 Department of Cell Biology and Histology, Academic Medical Center, Amsterdam, Netherlands \\ ${ }^{2}$ Department of Hematology, Academic Medical Center, Amsterdam, Netherlands \\ ${ }^{3}$ Tytgat Institute for Liver and Intestinal Research, Academic Medical Center, Amsterdam, Netherlands \\ ${ }^{4}$ Sanquin Research and Landsteiner Laboratory, Department of Hematopoiesis, Amsterdam, Netherlands
}

\section{Edited by:}

Uday Kishore, Brunel University, UK

Reviewed by:

Annapurna Nayak, Brunel University, UK

Benjamin M. J. Owens, University of Oxford, UK

\section{*Correspondence:}

Derk Amsen, Sanquin Research and Landsteiner Laboratory, Department of Hematopoiesis, Plesmanlaan 125, Amsterdam 1066 CX, Netherlands e-mail:d.amsen@sanquin.nl
Innate lymphoid cells (ILCs) are emerging key players of the immune system with close lineage relationship to T cells. ILC2 play an important role in protective immunity against multicellular parasites, but are also involved in the pathogenesis of type 2 immune diseases. Here, we have studied the developmental requirements for human ILC2. We report that ILC2 are present in the thymus of young human donors, possibly reflecting local differentiation. Furthermore, we show that uncommitted lineage ${ }^{-} \mathrm{CD} 34^{+} \mathrm{CD} 1 \mathrm{a}^{-}$human thymic progenitors have the capacity to develop into ILC2 in vitro under the influence of Notch signaling, either by stimulation with the Notch ligand Delta like 1 (DII1) or by expression of the active intracellular domain of NOTCH1 (NICD1). The capacity of NICD1 to mobilize the ILC2 differentiation program was sufficiently potent to override commitment to the T cell lineage in $\mathrm{CD}_{34}{ }^{+} \mathrm{CD} 1 \mathrm{a}^{+}$progenitors and force them into the ILC2 lineage. As Notch is an important factor also for $T$ cell development, these results raise the question how one and the same signaling pathway can elicit such distinct developmental outcomes from the same precursors. We provide evidence that Notch signal strength is a critical determinant in this decision: by tuning signal amplitude, Notch can be converted from a T cell inducer (low signal strength) to an ILC2 inducer (high signal strength). Thus, this study enhances our understanding of human ILC2 development and identifies a mechanism determining specificity of Notch signal output during T cell and ILC2 differentiation.

\section{INTRODUCTION}

A new group of hematopoietic effector cells has been identified in recent years, which is now commonly referred to as the innate lymphoid cell (ILC) family (1). Cells belonging to this family characteristically express the IL7R $\alpha$ chain (CD127), but lack markers specific for any other hematopoietic lineage. Members of this family are closely related to $\mathrm{T}$ cells, but do not express rearranged antigen receptors (2).

The ILC family displays broad functional diversity, which strikingly resembles that of $\mathrm{T}$ cells in terms of activating stimuli and signature cytokines secreted. For every $\mathrm{T}$ helper cell lineage, there appears to be a corresponding ILC lineage: group 1 ILC produce IFN $\gamma$ like T helper 1 cells (Th1) (3-5), ILC2 produce Interleukin 5 (IL-5) and IL-13 and are thus akin to Th2 cells (6-9), and members of the ILC3 lineage produce IL-17 and/or IL-22, resembling Th17 and Th22 cells (10-12). ILC secrete these factors in response to cytokines produced by epithelial and myeloid cells upon stress inflicted by pathogens. For instance, type 2 ILC respond to IL25 , IL-33, and thymic stromal lymphopoetin (TSLP), which are secreted by mast cells and epithelial cells (13). ILC2 are crucial for defense against helminth parasites (6) and involved in airway inflammation and tissue repair associated with influenza infections $(14,15)$. Accumulating evidence also implicates ILC2 in the pathogenesis of type 2 inflammatory diseases such as allergic asthma (16-20).

Like T cells, ILC2 are known to derive from a common lymphoid progenitor (CLP) (21-23). While developmental processes of ILC are only beginning to be explored, differentiation of T cells has been well characterized. T cell differentiation is initiated after migration of CLP to the thymus, the primary site of T cell development. Developing human T cells can be separated into several discrete stages. The earliest thymic progenitors express CD34, but lack expression of CD7 and CD1a $(24,25)$. These cells have been shown to retain myeloid potential in vitro (26), whereas CD7 upregulation restricts them to NK/T potential. Commitment to the T cell lineage is marked by upregulation of CDla (25). This is followed by rearrangement of T cell receptor $\beta$ genes. Once a fully rearranged in frame TCR $\beta$ gene is generated, its gene product combines with the pre-TCR $\alpha$ chain (pT $\alpha$ ) to form the pre-TCR, allowing a process called $\beta$-selection to take place. In humans, $\mathrm{TCR} \beta^{+}$cells first appear at an immature $\mathrm{CD} 4^{+}$stage (ISP $4^{+}$) stage (27). As a consequence of $\beta$-selection, cells expand massively, (further) upregulate $\mathrm{CD} 4$ and $\mathrm{CD} 8$ co-receptors and rearrange their TCR $\alpha$ genes to generate the mature TCR, which is subjected to positive and negative selection processes. Final differentiation of T cells into effector cells, such as Th1, Th2, or Th17 cells, does 
not occur until the cells are activated by cognate antigen in the secondary lymphoid organs.

Aside from the absence of antigen receptors, ILC clearly are distinct from $\mathrm{T}$ cells in their developmental requirements. Thus, ILC lineages depend on Id 2 for their development, whereas this factor is dispensable for T cell development. Also, the factor ROR $\alpha$ is essential for differentiation of ILC2 cells, but is not required for development of the corresponding Th2 subset, at least in vitro (20). Nonetheless, many parallels do exist between the factors that regulate differentiation of the various Th subsets and their ILC counterparts. For instance, $\mathrm{ROR} \gamma \mathrm{t}$ is required for generation of (murine) Th17 and group 3 ILCs (28), whereas evidence suggests that the lineage defining transcription factor for Th1 cells, Tbet (29), also regulates ILC1 differentiation (30). ILC2, on the other hand, depend on GATA3 for development and function, as do Th2 cells (31-34). Two additional factors known to govern $\mathrm{T}$ cell specification from thymic progenitors were recently shown to also be required for ILC2 differentiation, namely Tcf1 (35) and Notch (23).

Notch is a cell surface receptor, which is activated by binding to membrane bound ligands of the Delta like (Dll1 and Dll4) and Jagged (Jagged 1, Jagged 2) families. Ligand binding initiates a proteolytic cascade, which results in the release of the intracellular portion of the receptor, the Notch intracellular domain (NICD). NICD then translocates to the nucleus, where it associates with the DNA binding factor CSL [named after CBF-1 (mammals), $\mathrm{Su}(\mathrm{H})$ (Drosophila), and Lag-1 (C. elegans)]. Together, NICD and CSL recruit additional coactivators to induce transcription of target genes (36).

Notch signaling is absolutely required for at least two steps during the differentiation of $\mathrm{T}$ cells: $\mathrm{T}$ cell commitment and $\beta$-selection. The Notch pathway has also been implicated in differentiation of ILC (37). Lymphoid tissue inducer cells (LTi), which belong to the ILC3 group (1), require transient Notch activity at an early stage but Notch needs to be downregulated to allow for further differentiation of these cells (38). Depending on the microenvironment, Natural Cytotoxicity Receptor (NCR) ${ }^{+}$ ILC3 (named according to the expression of the NCR genes Nkp44/Nkp46) also might develop under the influence of Notch $(39,40)$. Finally, murine studies have demonstrated that group 2 ILC require Notch signaling for their development in vitro (23, 35). Whether Notch also regulates differentiation of human ILC2 has not been examined.

The involvement of Notch in differentiation of both ILC2 and $\mathrm{T}$ cells raises the question how activation of these pathways results in adoption of the T cell versus the ILC2 differentiation program. Two fundamentally different mechanisms are possible. First, the two cell types develop from different precursors, already more or less committed to either lineage. Alternatively, a common precursor gives rise to both cell types. In this scenario, the signals driving differentiation are distinct either qualitatively, involving additional signals dedicated to either lineage, or quantitatively.

Here, we examined these possibilities by studying Notch mediated in vitro differentiation of human thymocytes. We find that human thymic progenitors can give rise to both $\mathrm{T}$ cells and ILC2 in response to activation of Notch. Our data show that the strength of the Notch signal determines whether $\mathrm{T}$ cells or ILC2 are generated, with stronger signals favoring ILC2 differentiation. Thereby, we provide a mechanism explaining how the distinction between the T cell and ILC2 program can be made.

\section{RESULTS \\ GROUP 2 INNATE LYMPHOID CELLS CAN BE FOUND IN THE HUMAN THYMUS}

The close lineage relationship between T cells and group 2 ILCs (35) suggests that common precursors may exist for both lineages, which, depending on microenvironmental signals, differentiate into either T cells or ILC2. T cells differentiate in the thymus. Where ILC2 develop has not been established. There is evidence that these cells are generated in other locations than thymus, as suggested by the discovery of an ILC2 precursor in bone marrow $(32,41)$ and the presence of ILC2 in athymic FoxN1 ${ }^{\text {nu/nu }}$ (nude) mice $(23,42)$. However, these findings do not exclude the possibility that ILC2 can be generated in the thymus as well. If common precursors of ILC2 and T cells exist, which differentiate into ILC2 in the thymus, one would expect to find differentiated ILC2 in this organ. To examine this, we analyzed single cell suspensions of freshly isolated human thymocytes by multicolor flow cytometry for markers associated with group 2 ILC. ILCs were defined as CD45 ${ }^{+}$cells expressing high levels of the IL7R $\alpha$ chain (CD127), but lacking expression of markers specific for T cells (CD1a, CD3, TCR $\gamma \delta$, TCR $\alpha \beta$ ), B cells (CD19), hematopoietic stem cells (CD34), and other lineages (CD11c, CD14, CD94, CD123, FceR1, BDCA2), collectively termed "lineage" (Figure 1A, left). We found that an average of $0.0625 \%$ of $\mathrm{CD} 5^{+}$thymocytes belong to the ILC lineages. We further analyzed these IL7R $\alpha^{\text {high }}$ lineage ${ }^{-}$cells for the expression of CRTH2 (Figure 1A, right), which, within the family of ILCs, is specific for group 2 ILC (9). Using this strategy, we indeed detected a distinct population of CRTH $2^{+}$ILC in thymic specimens, on average accounting for $5 \%$ of the lineage ${ }^{-}$IL7R $\alpha^{\text {high }}$ ILC compartment (Figure 1C).

Phenotypically, thymic lineage ${ }^{-}$IL7R $\alpha^{\text {high }}$ CRTH2 ${ }^{+}$cells are similar to group 2 ILCs identified in other human tissues in that they express CD161 (9) and cKit (CD117) (Figure 1B), as was described for a subpopulation of human ILC2 (1). Furthermore, thymic lineage ${ }^{-}$IL7R $\alpha{ }^{\text {high }} \mathrm{CRTH} 2^{+}$cells do not express CD56 or NKp44 (Figure 1B), which are associated with conventional NK cells and ILC3 (1). These cells therefore adhere to what have been defined as the phenotypic hallmarks of human group $2 \operatorname{ILC}(2,9)$ and can thus be regarded as thymic ILC2.

The presence of ILC2 in the thymus is remarkable, because thus far, such cells have only been found in mucosal tissues in the intestine and airways, consistent with their role in innate border patrol, in blood (9), presumably reflecting their migration, and in bone marrow, the major site of hematopoiesis $(8,34)$. Although we did not formally test whether ILC2 differentiation takes place in the human thymus, the fact that such cells are found at relatively high numbers in the thymus is consistent with the possibility that these cells are generated in this non-inflamed organ. 

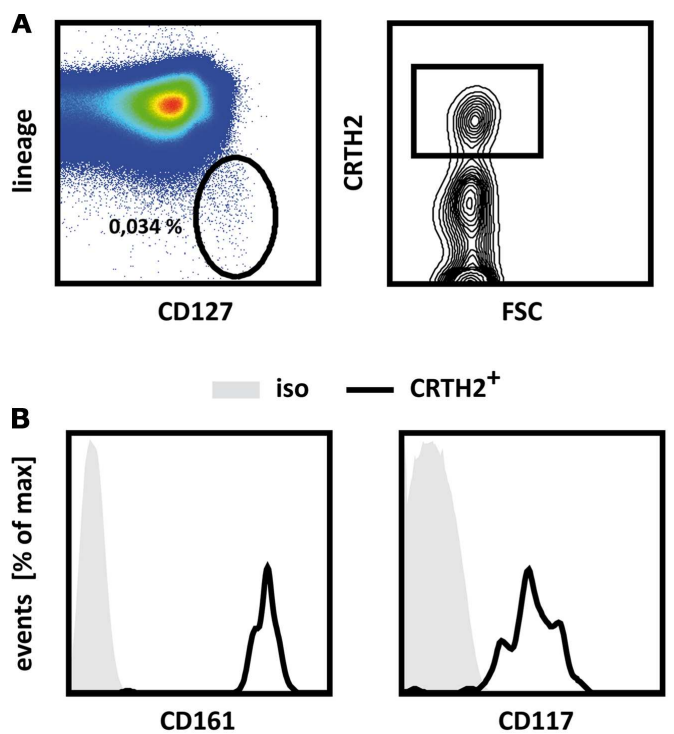
$\mathrm{CRTH}^{+}$
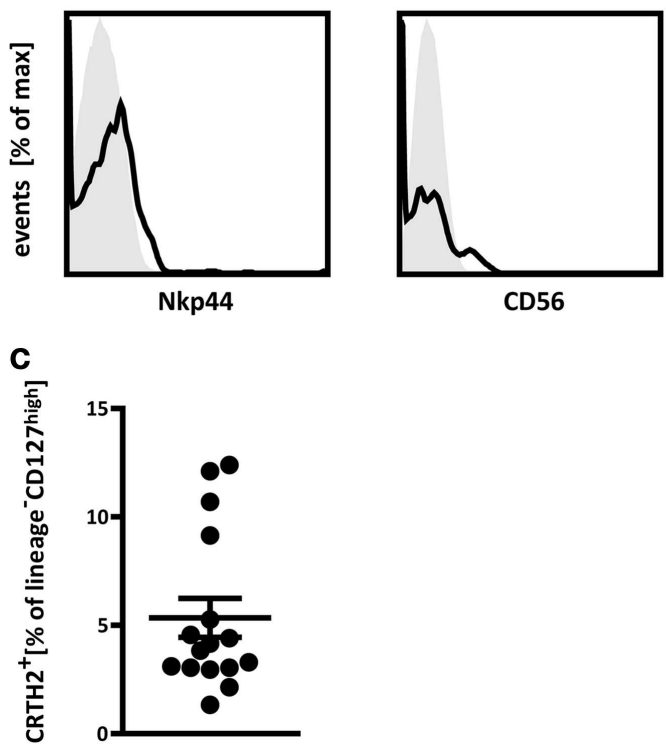

FIGURE 1 | Human thymus contains group 2 innate lymphoid cells. (A) Gating strategy applied to identify thymic ILC2. Thymocytes were pre-gated for $C D 45^{+}$cells and innate lymphoid cells were defined as lineage ${ }^{-}\left(C D 1 a^{-}\right.$CD3 ${ }^{-}$CD 11 ${ }^{-}$CD 14- CD19- CD34- CD123-TCR $\alpha \beta^{-}{ }^{-}$TCR $\gamma \delta^{-}$ BDCA2 ${ }^{-} \mathrm{F}_{\mathrm{C} \varepsilon \mathrm{RI}^{-}}$) $\mathrm{CD} 127^{\text {high }}$ cells (left). This population was further analyzed for the presence of $\mathrm{CRTH}_{2}{ }^{+}$cells (right). Percentages of cells in the respective gates are displayed. (B) Flow cytometric analysis of the expression of CD161, CD117 (cKit), Nkp44, and CD56 by thymic ILC2 as defined in (A). Representative FACS plots from a single donor are shown (A,B). (C) Relative abundance of ILC2 in human thymic specimens from a total of 16 donors analyzed $(\mathbf{C})$. Results in $(\mathbf{C})$ are shown as mean $\pm \mathrm{SEM}$.

\section{IN VITRO DIFFERENTIATION OF ILC2 FROM THYMIC PROGENITORS BY NOTCH SIGNALING}

Given the presence of innate group 2 lymphocytes in the human thymus, we asked whether these cells can develop directly from thymic progenitors. A recent study showed that ILC2 differentiation can be induced from murine bone marrow-derived common lymphoid and thymic progenitors by co-culture with OP9 stromal cells expressing the Notch ligand Dll1 (23). To test whether human thymic progenitors have the capacity to differentiate into ILC2, we initiated OP9 co-cultures with human $\mathrm{CD} 34^{+} \mathrm{CD} 1 \mathrm{a}^{-}$thymocytes, which have not yet committed to the T lineage (43). Although some lineage ${ }^{-}$IL7R $\alpha^{+} \mathrm{CRTH}_{2}{ }^{+}$cells appeared after 1 week of culture with control OP9 cells, the frequency of such cells was significantly increased upon co-culture with OP9 Dll1 (Figure 2A). Under these same conditions, OP9 Dll1 cells also induced differentiation of T cells, as expected, but this process required minimally 2 weeks of co-culture (Figure 2B).

Interestingly, when OP9 Dll1 co-cultures were initiated with thymic $\mathrm{CD} 34^{+} \mathrm{CD} 1 \mathrm{a}^{+}$progenitors, which are believed to already have committed to the $\mathrm{T}$ cell lineage (43), enhanced induction of lineage ${ }^{-}$IL7R $\alpha^{+}$CRTH2 $2^{+}$cells by OP9 Dll1 was not detected (Figure 2C). This indicates that these progenitors might have lost the potential to differentiate into the ILC lineage, as has been demonstrated for murine thymic DN3 cells (23).

\section{CONSTITUTIVE NOTCH1 ACTIVATION ROBUSTLY INDUCES DIFFERENTIATION OF LINEAGE-IL7R $\alpha^{+}$CRTH2 ${ }^{+}$CELLS}

OP9 cells expressing Dll1 have widely been used to induce Notch dependent $\mathrm{T}$ cell differentiation (44). It is not immediately obvious how activation of Notch in the same progenitors would induce two distinct differentiation programs, namely ILC2 or $\mathrm{T}$ cells. Although Notch is clearly required in a cell intrinsic manner in thymic progenitors during $\mathrm{T}$ cell differentiation (45), this has not been established for ILC2. Indeed, it is conceivable that ILC2 induction by OP9 Dll1 would be an indirect effect from lateral Notch activation in the OP9 cells, resulting in production of other signals by these cells, which promote ILC2 differentiation. To test whether cell intrinsic Notch signaling in thymic progenitors induces ILC2 differentiation, we ectopically expressed the intracellular domain of NOTCH1 (NICD1) in thymic $\mathrm{CD} 34^{+} \mathrm{CD} 1 \mathrm{a}^{-}$progenitors, thereby inducing constitutive activation of NOTCH1 in these cells, and subjected these to co-culture on control OP9 cells. NICD1 expression resulted in robust induction of an IL7R $\alpha^{+} \mathrm{CRTH} 2^{+}$population, which lacks expression of T cell (CD1a, CD3, CD4, CD8, TCR $\alpha \beta, \mathrm{TCR} \gamma \delta)$ and other lineage markers (CD11c, CD14, CD19, CD34, CD94, CD123, FceR1, BDCA2) (Figure 3A). Thus, direct activation of Notch in thymic $\mathrm{CD} 34^{+} \mathrm{CD} 1 \mathrm{a}^{-}$progenitors results in the differentiation of cells resembling ILC2 cells.

A prominent population of lineage ${ }^{-} \mathrm{CRTH} 2^{+}$cells was usually present after 1 week, but these cells first appeared after as little as 4 days of co-culture on OP9 cells, and persisted for up to 2 weeks (Figure 3B). NICD1 induced differentiation of lineage ${ }^{-}$IL7R $\alpha^{+} \mathrm{CRTH}_{2}{ }^{+}$cells was subject to donorto-donor variation. However, ectopic NICD1 expression consistently induced a prominent lineage ${ }^{-} \mathrm{IL7R} \alpha^{+} \mathrm{CRTH} 2^{+}$population (Figure 3C).

Strikingly, NICD1 even robustly induced a lineage ${ }^{-}$IL7R $\alpha^{+}$ $\mathrm{CRTH} 2{ }^{+}$population from $\mathrm{T}$-committed $\mathrm{CD} 34^{+} \mathrm{CD} 1 \mathrm{a}^{+}$thymic progenitors, although to a lesser degree than from uncommitted $\mathrm{CD} 34^{+} \mathrm{CD} 1 \mathrm{a}^{-}$thymocytes (compare Figures 3C,D). This suggests that strong, sustained Notch signaling can overcome commitment to the $\mathrm{T}$ cell lineage in thymic progenitors and therefore challenges 


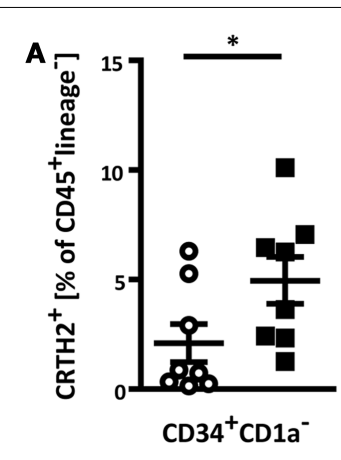

FIGURE 2 |Thymic progenitors can differentiate into ILC2 in vitro by Notch activation. (A) Flow cytometric analysis of ILC2 differentiation from thymic $\mathrm{CD} 34^{+} \mathrm{CD} 1 \mathrm{a}^{-}$progenitors. Cells were cultured on control OP9 or OP9 DIl1 as indicated for 1 week. ILC2 were defined as $\mathrm{CD} 45^{+}$lineage ${ }^{-} \mathrm{CRTH} 2^{+}$. (B) $\mathrm{CD} 34^{+} \mathrm{CD} 1 \mathrm{a}^{-}$progenitors were cultured on OP9 cells as indicated. After
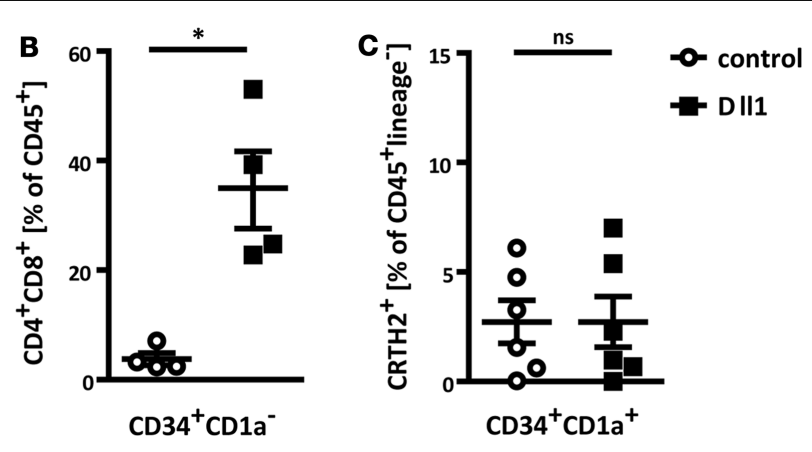

the lineage fidelity of these precursors. Strikingly, ectopic expression of NICD1 in $\mathrm{CD} 34^{+} \mathrm{CD} 1 \mathrm{a}^{-}$thymocytes also resulted in a prominent lineage ${ }^{-} \mathrm{IL} 7 \mathrm{R}^{+}{ }^{+} \mathrm{CRTH} 2^{+}$population when thymic progenitors were cultured in the combined presence of IL-7 and Flt3l (Figure 3E), conditions known to promote development into the $\mathrm{T}$ cell lineage $(46,47)$.

Collectively, these data show that activation of Notch in human thymic hematopoietic progenitors activates the ILC2 differentiation program. Indeed, the connection between Notch and the ILC2 differentiation program is potent enough to dismantle the $\mathrm{T}$ cell differentiation program in cells already committed to the $\mathrm{T}$ cell lineage and make them adopt the ILC2 fate instead.

The transcription factor GATA3 has been shown to play an essential role in development and function of both murine and human ILC2 $(32,33)$. Overexpression of GATA3 in a population of lineage ${ }^{-} \mathrm{CD} 127^{+} \mathrm{CD} 117^{+} \mathrm{Nkp} 44^{-} \mathrm{CRTH} 2^{-}$immature ILC was sufficient to drive these cells into the ILC2 lineage (33). To determine whether GATA3 is also able to elicit ILC2 differentiation from thymic progenitors, we ectopically expressed this factor from a retroviral vector in $\mathrm{CD} 34^{+} \mathrm{CD} 1 \mathrm{a}^{-}$uncommitted progenitors and monitored ILC2 differentiation. Indeed, GATA3 expression was sufficient to induce an ILC2 phenotype (Figure 3F), further supporting the notion that thymic progenitors have the capacity to differentiate into genuine ILCs. However, NICD1 was more potent in ILC2 differentiation in direct comparison with GATA3, at least at the expression levels obtained by our retroviral expression systems (Figure 3F).

\section{NOTCH1 INDUCED CRTH2+ CELLS ARE BONA FIDE ILC2}

Thus far, our interpretation that Notch activation instructs thymic progenitors to differentiate into ILC2 cells has been based on the absence of lineage markers (including those defining $\mathrm{T}$ cells) and the presence of CRTH2, a marker supposedly not found in immature $\mathrm{T}$ cells. However, given the wealth of data demonstrating the role of Notch in differentiation of $\mathrm{T}$ cells, it is conceivable that the cells obtained here represent a previously not described subtype of immature T cells. Also, it is possible that our results reflect atypical expression of CRTH2 on T cell lineage cells, for instance as
2 weeks, the abundance of $\mathrm{CD} 4^{+} \mathrm{CD} 8^{+} \mathrm{T}$ cells was assessed. (C) Thymic $\mathrm{CD} 34^{+} \mathrm{CD} 1 \mathrm{a}^{+}$progenitors were cultured and ILC2 development was measured as in (A). Data are shown as mean \pm SEM from minimally four independent experiments. Mann-Whitney test was performed for statistical analyses, ${ }^{*} p<0.05$. a consequence of direct transactivation of the gene encoding this marker by Notch. We therefore sought to determine whether the $\mathrm{CRTH} 2^{+}$cells differentiated from thymic progenitors in response to Notch are genuine group 2 ILCs.

To this end, we performed more extensive phenotyping by multi-color flow cytometry, examining the surface expression of several markers known to be associated with human ILC2. As described above (Figure 3A), $\mathrm{NICD}^{+}\left(\mathrm{CRTH} 2^{+}\right)$cells express the IL7R $\alpha$ chain (Figure 4A), although surface levels varied between experiments and were sometimes lower than those found on freshly isolated ILCs. This is most likely due to in vitro culture in the presence of recombinant IL-7, which results in receptor internalization (48). Indeed, such down regulation of IL7R $\alpha$ has also been observed when freshly isolated mature ILC2 cells were cultured in vitro (9). NICD1 induced CRTH2 ${ }^{+}$cells express low levels of KLRB1 (CD161) in a bimodal distribution (Figure 4A) as has been shown for human ILC derived from other tissues (9). Additionally, NICD1 induced CRTH2 ${ }^{+}$cells also express CD25 (the IL-2R $\alpha$ chain), CD7, and ICOS, all of which have been shown to be expressed by group 2 ILCs $(1,9)$. CRTH $2^{+}$cells differentiated in vitro by Notch activation for the most part do not express cKit (Figure 4A). The interpretation of this observation is complicated by the fact that expression of cKit by human group 2 ILC is variable. Among human fetal gut and peripheral blood ILC2, both a $\mathrm{cKit}^{+}$and $\mathrm{cKit}^{-}$population have been described (9). Expression of cKit, therefore, does not seem to constitute part of the core ILC2 identity. Finally, NOTCH1 induced $\mathrm{CRTH}_{2}{ }^{+}$cells do not show surface expression of CD56 and Nkp44 (Figure 4A), associated with the NK and other ILC subsets (1). Taken together, the expression pattern of these surface markers shows that CRTH2 ${ }^{+}$ cells derived from thymic progenitors by Notch mediated in vitro differentiation phenotypically resemble bona fide ILC2 found in the thymus and various other human tissues.

To further characterize these Notch induced thymic ILC2, we determined mRNA expression levels of lineage defining transcription factors, cytokine receptors, and signature cytokines in cells directly isolated from differentiation cultures (Figure 4B). Cells differentiated from thymic progenitors in vitro by expression 


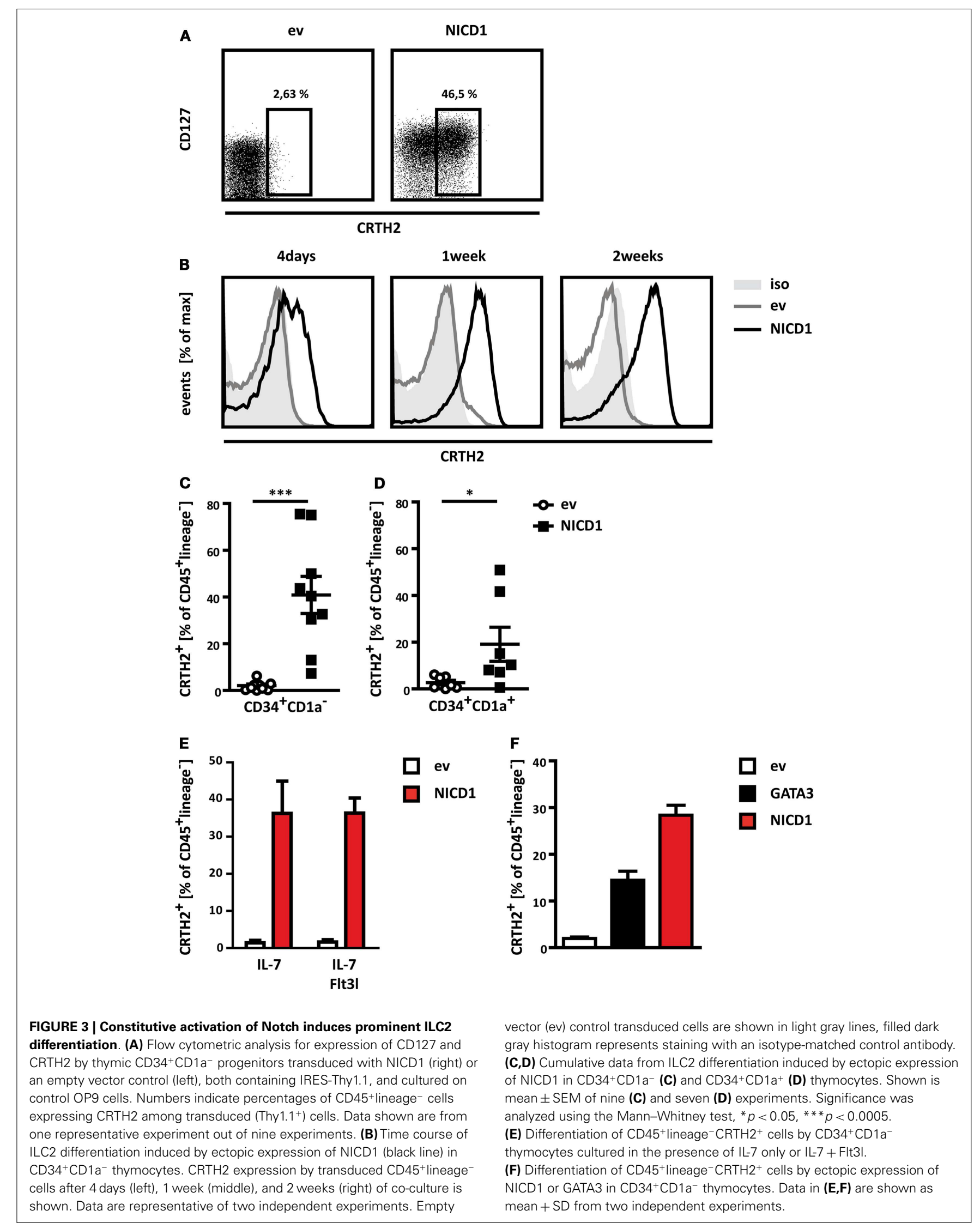



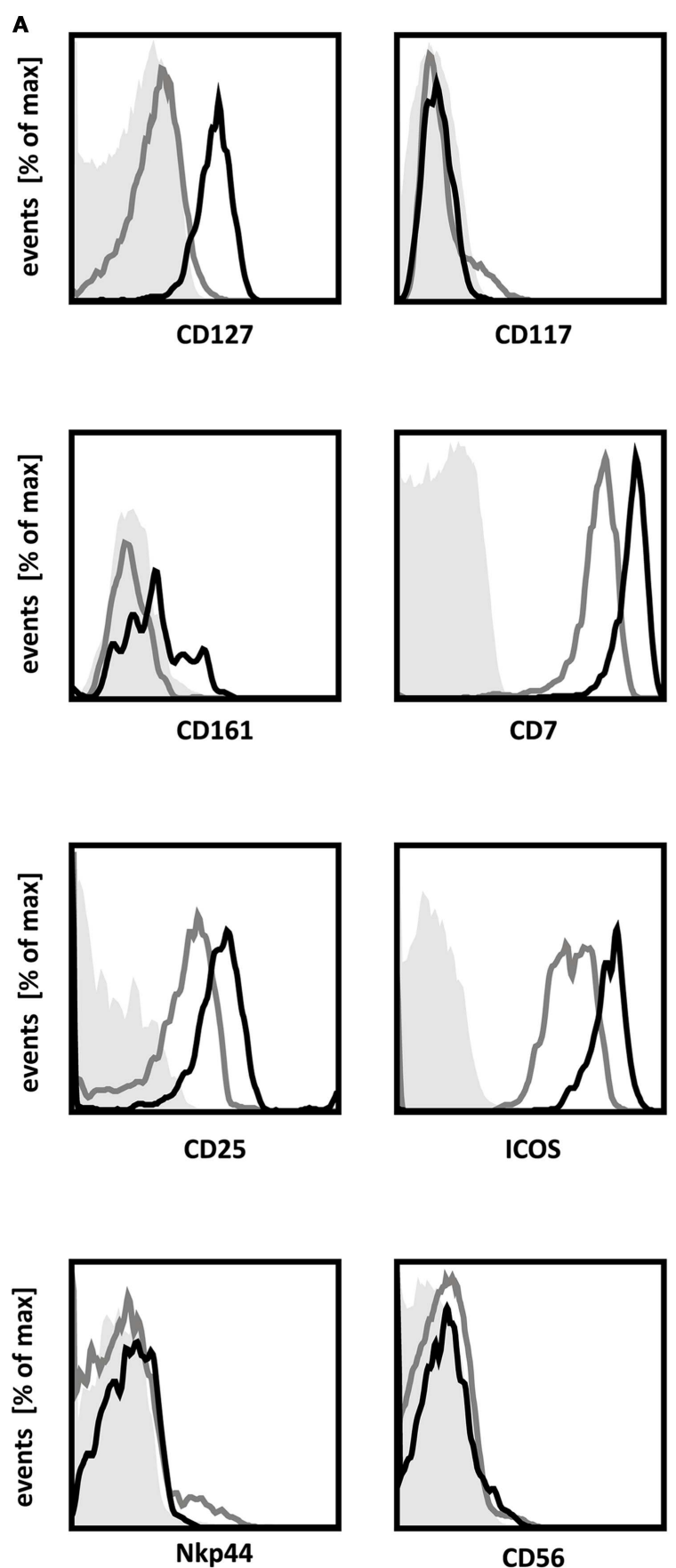

FIGURE 4 | NICD1 induced lineage ${ }^{-}$CRTH2 ${ }^{+}$cells are bona fide ILC2. (A) Flow cytometric analysis of surface expression of CD127 (IL7R $\alpha$ ), CD117 (cKit), CD161, CD7, CD25, ICOS, CD56, and Nkp44 on Thy 1.1+ thymocytes transduced with NICD1-IRES-Thy1.1-MSCV (black line) or IRES-Thy1.1-MSCV empty vector (ev, gray line) and differentiated in vitro on control OP9 cells. Gray shaded: isotype-matched control antibody. FACS data are representative of minimally three experiments. (B) Expression of
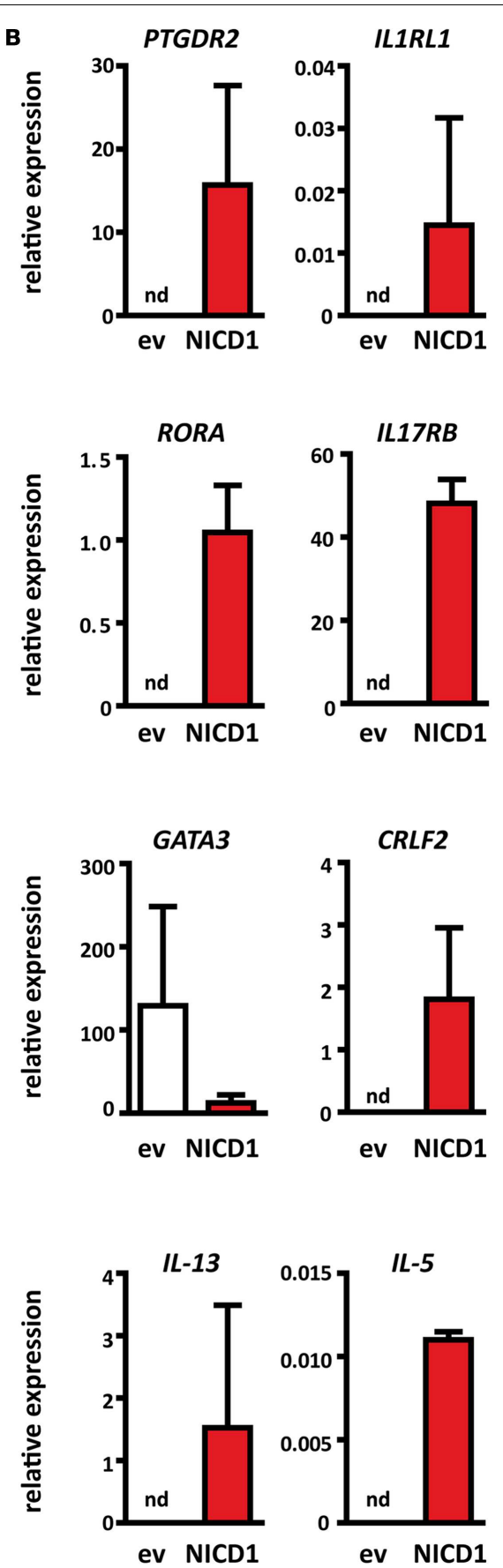

PTGDR2 (CRTH2), IL 1RL 1 (ST2), IL 17RB (IL-25R), CRLF2 (TSLP-R), RORA, GATA3, IL-5, and IL-13 mRNA in thymocytes transduced and differentiated in vitro as in (A). Cells were sorted after 1 week of culture as NICD1 (red bars) or empty vector transduced (ev, white bars) on the basis of Thy 1.1 expression. Expression levels were normalized to the housekeeping gene $\beta$-Actin. nd, Not detectable. Data are shown as mean + SD of two independent experiments. of NICD1 expressed transcripts for the lineage specific cytokine receptors IL1RL1 (ST2, a subunit of the IL-33 receptor), IL17RB (a subunit of the receptor for IL-25), and CRLF2 (TSLP-R).
Together with CD25 (Figure 4A), these cells thus express the critical receptors to respond to the ILC2 activating cytokines IL2, IL-25, IL-33, and TSLP. Notably, expression of transcripts for 
these cytokine receptors was not detected in empty vector control cells (Figure 4B). In vitro differentiated ILC2 also expressed RORA mRNA encoding the ILC2 lineage specific transcription factor ROR $\alpha$. However, these cells did not express elevated levels of GATA3 compared to control cells. This may seem counterintuitive, given the ability of GATA3 to induce ILC2 differentiation from thymic progenitors (Figure 3E) and the fact that GATA3 is a known direct target of Notch signaling (49-51). However, it should be noted that expression of GATA3 is low also in resting ILC2 derived from peripheral tissues after in vitro culture and that expression of this factor is elevated only after exposure to activating stimuli such as TSLP (33). Therefore, high constitutive expression of GATA3 does not seem to be a characteristic of resting human ILC2 cells. Most strikingly, even without exogenous activation, $\mathrm{NICD}^{+}$cells expressed transcripts for the ILC2 signature cytokines $I L-13$ and $I L-5$ (Figure 4B), whereas empty vector control cells did not, further reinforcing the interpretation that $\mathrm{NICD} 1$ induced $\mathrm{CRTH}_{2}{ }^{+}$cells are fully functional group 2 ILC. Constitutive expression of IL-5 and IL-13 transcripts by unstimulated ILC2 has been observed previously in the fetal gut (9). We therefore conclude that ILC2 differentiated in vitro from thymic progenitors by activation of NOTCH1 resemble bona fide group 2 ILCs.

\section{NOTCH PROMOTES T CELL VERSUS ILC2 DIFFERENTIATION IN A SIGNAL STRENGTH DEPENDENT MANNER}

The fact that activation of Notch can induce differentiation of both T cells and ILC 2 from the same thymic progenitors raises the question what determines which of these differentiation programs is turned on. The Notch pathway is sensitive to signal amplitude, which allows induction of discretely different responses by one and the same signaling pathway $(52,53)$. Given our findings that expression of NICD1 was much more potent at eliciting ILC2 differentiation than co-culture with OP9 Dll1, we reasoned that the strength of the Notch signal might be a critical factor deciding whether T cells or ILC2 are generated.

To test this hypothesis, we generated an expression construct, in which the concentration of nuclear NICD1 can be controlled in a quantitative manner. In this construct, NICD1 is N-terminally fused to a mutated Estrogen receptor ligand binding domain (mER). This mutated domain no longer binds Estrogen, but does respond to Tamoxifen (54). In the absence of this drug, mERNICD1 is bound by heat shock proteins in the cytoplasm and hence kept transcriptionally inactive. Addition of Tamoxifen to the culture medium induces transcriptional activity of mER-NICD1 in a dose-dependent manner (Figure 5A). Some leakiness is frequently observed with these types of ER-fusion proteins $(55,56)$ and indeed, we also consistently observed weak but significant activity of mER-NICD1 in the absence of Tamoxifen (Mock) on two different Notch-responsive promoters (Figure 5A). Therefore, this tool enabled us to induce different levels of NOTCH1 activation, and even explore the impact of very low levels owing to the leakiness of the mER system. In comparison, expression of constitutively active NICD1 served to induce high signaling strength. Together, these constructs allowed us to examine the consequences of Notch signaling across a more than 100 -fold dynamic range, as measured in reporter gene assays (compare luciferase activities in the absence of Tamoxifen with those obtained with expression of constitutively active NICD1 in Figure 5A).

To test whether Notch signal strength affects ILC2/T cell differentiation, we retrovirally expressed mER-NICD1 or constitutive $\mathrm{NICD} 1$ in uncommitted, CD34 ${ }^{+} \mathrm{CD} 1 \mathrm{a}^{-}$thymic precursors, subjected these to co-culture on control OP9 cells and titrated in Tamoxifen. The activity of the mER-NICD1 and NICD1 constructs could also be controlled quantitatively in these cells, as shown by the Tamoxifen dose-dependent induction of CD7 expression (Figure 5B), which we have found to be a sensitive gauge for Notch activity in thymic precursors.

Using this system, we measured differentiation of $\mathrm{T}$ cells as well as group 2 ILC by flow cytometry. We chose to examine the development of these cells after 2 weeks because of the different kinetics in T cell and ILC2 differentiation. Differentiation of T cells generally requires incubation periods of at least 2 weeks (57) (Figure 2B). As shown before (Figure 3B), group 2 ILC populations emerge within several days of culture, but persist longer and could therefore be assessed here after 2 weeks in direct comparison with T cells.

As expected, neither $\mathrm{T}$ cell differentiation nor generation of ILC2 occurred effectively in the absence of Notch activation: considerable populations of both $\mathrm{CD} 4{ }^{+} \mathrm{CD} 8 \alpha^{+} \mathrm{T}$ cells (Figure 5C) and lineage ${ }^{-}$IL7R $\alpha^{+}$CRTH2 ${ }^{+}$ILC2 (Figure 5D) only arose from cultures which had received a Notch signal by means of ectopic NICD1 expression, but not in empty vector transduced control cultures. With regard to dosage dependence, however, T cell and ILC2 differentiation displayed opposite requirements: even very low doses of Notch activity were sufficient to elicit development of T-lineage cells (Figure 5C). In fact, the lowest levels of NOTCH1 signaling activity, owing to the leakiness of our system in the absence of Tamoxifen (see above), gave rise to the most prominent $\mathrm{T}$ cell differentiation (almost $20 \%$ of $\mathrm{CD} 4{ }^{+} \mathrm{CD} 8 \alpha^{+} \mathrm{T}$ cells), whereas hardly any ILC2 were observed in this condition (Figure 5D). Titrating in Tamoxifen to induce higher levels of NOTCH1 signaling gradually diminished the number of $\mathrm{T}$ cell lineage cells obtained (Figure 5C). In contrast, stronger NOTCH1 induced more ILC2 differentiation (Figure 5D). Most strikingly, the highest level of Notch signaling, induced here by constitutively active NICD1, did not yield any T cells (Figure 5C); instead, constitutive NICD1 expression resulted in the most prominent ILC2 differentiation (Figure 5D). Taken together, these results demonstrate that by varying signal strength, one and the same Notch pathway can activate two distinct differentiation programs, with weaker signals favoring development of T cells and stronger signals inducing more efficient ILC2 differentiation.

\section{DISCUSSION}

ILC are increasingly recognized as important mediators of immunity and lymphoid tissue (re)modeling (2). The mechanisms underlying differentiation of these cells and the anatomical locations where these processes take place are only beginning to be characterized. What is known has mostly been learned from studies in mice. Here, we have studied the differentiation of human ILC2.

We report the identification of ILC2 in the human thymus. The presence of ILC2 in the thymus could theoretically be explained 


\section{A

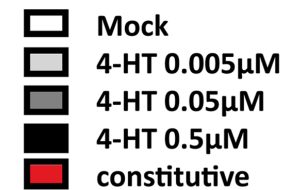

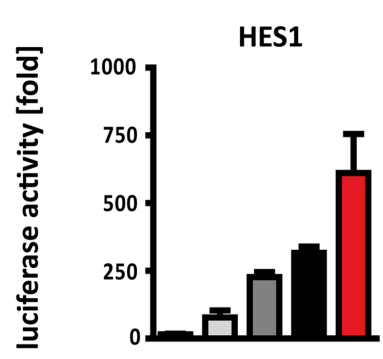

B

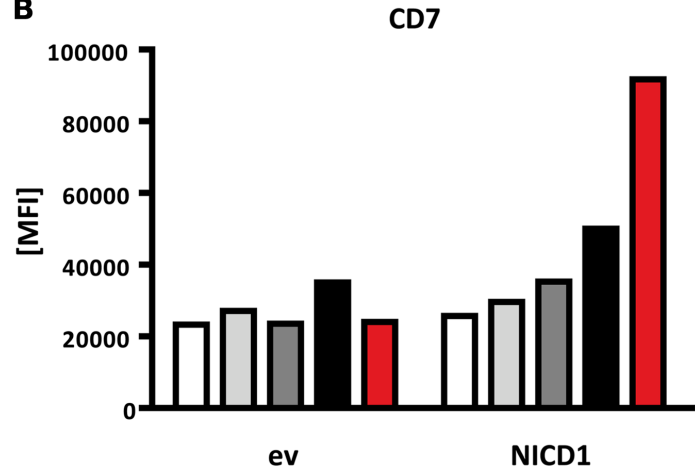

FIGURE 5 | Notch promotes differentiation of T cells versus ILC2 in a signal strength dependent manner. (A) Activation of the Notch-responsive reporter constructs HES1-luciferase (left) and CBF-1-luciferase (right) induced by different levels of nuclear release of mER-NICD1 or constitutive NICD1 expression. U2OS cells were transfected with a mixture of reporter plasmids expressing Firefly luciferase, a plasmid constitutively expressing Renilla luciferase and an empty vector control, mER-NICD or NICD1, respectively. 4-Hydroxytamoxifen (Tamoxifen, 4-HT) was added at the indicated concentrations. Firefly luciferase activities were normalized to Renilla luciferase activities from the same samples and are displayed as fold of empty vector control samples at the respective concentration of

\section{C}

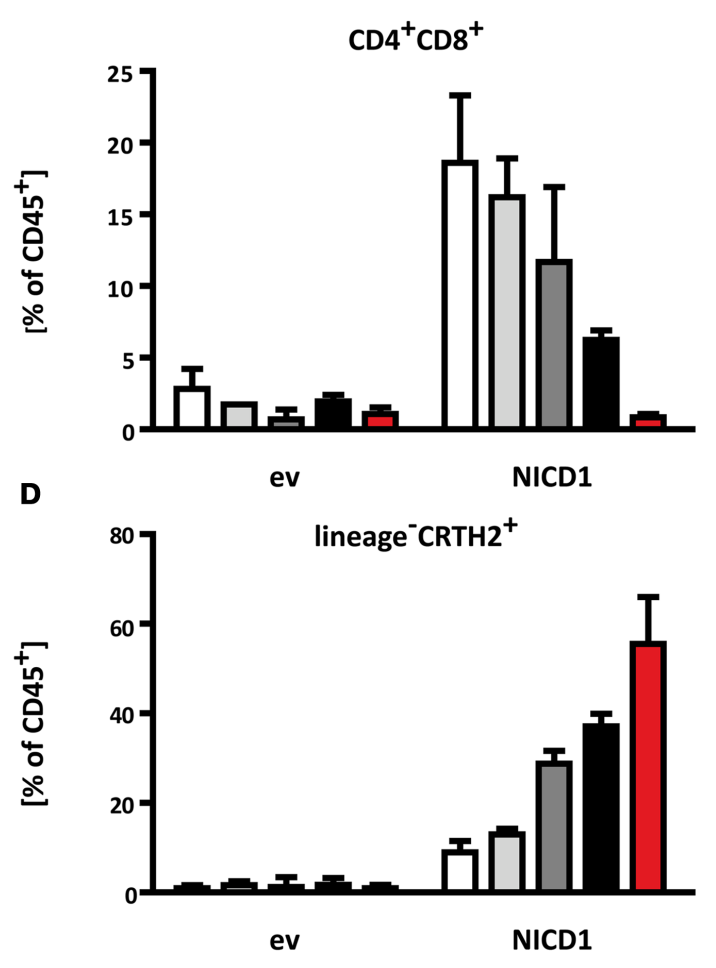

Tamoxifen. Data shown are from one representative of three independent experiments performed in triplicate (mean + SD). (B-D) Flow cytometric analysis of thymocytes after 2 weeks of co-culture on control OP9 cells. $\mathrm{CD} 34^{+} \mathrm{CD} 1 \mathrm{a}^{-}$progenitors were transduced with NICD1, mER-NICD1, or an empty vector control prior to co-culture. Tamoxifen was added to mER-NICD1 and empty vector transduced cultures at the concentrations indicated. (B) Levels of CD7 expression are displayed as MFI. Data shown are from one representative experiment from 2 similar experiments. (C) Transduced cells were analyzed for surface expression of CD4 and CD8 to assess T cell differentiation. (D) ILC2 differentiation as determined by expression of CRTH2 on transduced lineage ${ }^{-}$cells. Data displayed in (C) and (D) are cumulative from three independent experiments (mean + SD). by migration to this site, although it is not clear what the function of such recruitment would be. The currently known function of ILC2 consists of defense at epithelial barriers (58) and it seems unlikely that ILC2 would be required for this purpose in a sterile internal organ such as the thymus. It is of course conceivable that ILC2 have additional, not identified functions, for instance in tissue homeostasis or development, which explain their presence in this organ. An alternative explanation for their presence in the thymus is that ILC2 are in fact generated in this organ, although the thymus is likely not the only site of ILC2 development. At face value, a role for the thymus in differentiation of ILC2 may seem at odds with a study reporting the identification of a Lin $^{-}$Sca ${ }^{\text {hi }}$ Id $2^{\text {hi }}$ GATA $3^{\text {hi }}$ (LSIG) ILC2 precursor in murine bone marrow (20,32). However, transcriptome analysis and adoptive transfer experiments suggested that these cells have already committed to the ILC2 lineage and may represent an immature ILC2 stage. Whether differentiation of progenitors into this immature
ILC2 stage could also take place in the thymus was not addressed directly in these studies. Another mouse study directly addressed the question whether the thymus is essential for ILC2 development (23). Wong and colleagues made use of FoxN1 ${ }^{\text {nu/nu }}$ (nude) mice, which display defective thymus development (59). Normal numbers of group 2 ILC were found in mesenteric lymph nodes in these mice after injection of IL-25 (23). While this formally proves that ILC2 differentiation can occur at extrathymic sites, at least in mice, this study does not address whether this process also occurs in the thymus.

Whether ILC2 differentiation occurs in the human thymic organoid could be investigated using humanized immune system mice (60). Furthermore, studies of patients with DiGeorge syndrome, who have defects in thymic development like FoxN1 ${ }^{\text {nu/nu }}$ (nude) mice (61), could provide valuable insights. However, it stands to reason that, if ILC2 do develop in the thymus, progenitors with the capacity to differentiate into group 2 ILC must exist 
in this organ. Our finding that $\mathrm{CD} 34^{+} \mathrm{CD} 1 \mathrm{a}^{-}$cells differentiate into ILC2 in response to activation of Notch shows that this is indeed the case.

Recent studies underline the close genetic relationship between $\mathrm{T}$ and ILC2 cells, the latter expressing a multitude of markers which classically have been considered T-lineage genes, such as CD7, Lck, Lat, Bcl11b, and $\operatorname{Tcf} 7(6,35)$. Indeed, thymic lineage ${ }^{-} \mathrm{CD} 34^{+} \mathrm{CD}^{-} \mathrm{a}^{-}$cells can develop into both ILC2 and T cells, as we show here. Expression of CD1a by these cells has been considered to mark their commitment to the T cell lineage (43). Correspondingly, we found that $\mathrm{CD} 34^{+} \mathrm{CD} 1 \mathrm{a}^{+}$progenitors failed to give rise to ILC2 after co-culture on OP9 Dll1. However, the ability to differentiate into ILC2 was not lost completely by these cells, as ectopic expression of the NICD1, which we found to be a much stronger stimulus for ILC2 differentiation than OP9 Dll1 cells, could still divert these cells into ILC2. A gradual decrease in ILC2 potential was reported also for murine progenitors: ILC2 differentiation in vitro was induced efficiently by OP9 Dll1 when $\mathrm{CD} 44^{+} \mathrm{CD} 25^{-} \mathrm{CD} 4^{-} \mathrm{CD} 8^{-}$double negative 1 (DN1) cells were used, less efficiently when using $\mathrm{CD} 44^{+} \mathrm{CD} 25^{+} \mathrm{DN} 2$ cells, and not at all with $\mathrm{CD} 44^{-} \mathrm{CD} 25^{+} \mathrm{DN} 3$ cells (23), which are thought to be fully committed to the $\mathrm{T}$ cell lineage (62).

Many studies have shown that thymic $\mathrm{CD} 34^{+} \mathrm{CD}^{-}{ }^{-}$cells differentiate into $\mathrm{T}$ cells when cultured on OP9 stroma cells expressing the Notch ligand Dll1 $(46,63)$. It was surprising, therefore, that differentiation of ILC2 was also obtained using the same conditions and progenitors in our experiments. Our data reveal that the strength of the Notch signal is an important parameter in this decision, with lower Notch signals mediating $\mathrm{T}$ cell differentiation, while strong Notch signals induce ILC2 differentiation. Similar dosage dependent outcomes of Notch signaling have been reported before (64), for instance in the lineage decision between $\alpha \beta$ and $\gamma \delta \mathrm{T}$ cells $(52,65)$. While we did not observe $\gamma \delta \mathrm{T}$ cells in our cultures, possibly due to differences in culture conditions and progenitor sort strategies, the block in $\alpha \beta \mathrm{T}$ cell development observed here with high levels of Notch activation is in line with these studies (65). Two non-mutually exclusive mechanisms can be envisioned to explain how a subset of progenitor cells receives the strong Notch signals required for differentiation of ILC2. First, specialized niches with high levels of Notch ligands may exist in the thymus and/or hematopoietic organs (66, 67). Both cortical and medullary epithelial cells (TEC) express the Notch ligands Dll1, Dll4, Jag1 and Jag2 in humans (66). However, other components of the thymic stroma, for instance thymic DCs (68), also express Notch ligands. Second, the CD34 ${ }^{+} \mathrm{CD} 1 \mathrm{a}^{-}$ population may contain a mixture of cells with high and low sensitivity to Notch ligands. Such differential sensitivity may for instance be achieved through modification by Fringe glycosylases, expression of different levels of Notch and downstream mediators or pathway modifiers $(69,70)$. This diversification may itself be influenced by factors produced in specialized niches. Indeed, factors such as TGF $\beta$, Wnt, and type I interferons can all modify the maximum amplitude of Notch signaling through various ways (64) (Amsen, unpublished data). TECs produce TGF $\beta$ (71), while thymic plasmacytoid DCs constitutively express IFN $\alpha$ under non-inflamed conditions (72), indicating once more that both epithelial and non-epithelial stromal components of the thymic microenvironment might contribute to specialized niches capable of eliciting strong Notch signals in developing thymocytes. Given that mice lacking thymic epithelial cells still generate ILC2 (23), it is tempting to speculate that the relevant source of the Notch activating signals consists of a non-epithelial stromal cell.

The prominent induction of ILC2 differentiation by strong Notch signaling echoes a similar role for Notch in differentiation of T helper 2 cells, which are functionally related to ILC2 (73). Induction of Th2 differentiation by Notch involves direct transactivation of GATA3 in $\mathrm{CD} 4{ }^{+} \mathrm{T}$ cells $(31,50,51)$. Since GATA3 is also essential for the generation and function of murine and human ILC2 $(32,33)$, it seemed likely that Notch mediated ILC2 differentiation would also proceed via induction of this transcription factor, at least partially. To our surprise, however, GATA3 levels were not elevated by Notch signaling during differentiation of ILC2 cells from $\mathrm{CD} 34^{+} \mathrm{CD}_{1} \mathrm{a}^{-}$cells. Although not elevated, GATA3 expression was still clearly detectable in these cells, suggesting that Notch mediated ILC2 development might not be completely independent of GATA3. Nonetheless, it seems likely that Notch induces the ILC2 fate predominantly via activation of other genes. Interestingly, some of the genes shared between the T cell and ILC2 programs $(6,35), \mathrm{Tcf} 1$ and Bcl1 1b, are established direct targets of Notch $(74,75)$. Direct transactivation of such genes would provide at least a partial explanation for the ability of Notch to induce ILC2 differentiation without elevating expression of GATA3, although it seems likely that also other direct Notch targets exist, which are dedicated to the ILC2 differentiation program. One mechanistic explanation for the high Notch signal strength dependence of ILC2 differentiation might be that transactivation of such dedicated target genes requires higher concentrations of NICD, for instance due to steric impediment by factors surrounding the Notch-responsive elements.

In summary, we show that the human thymus contains ILC2. Whether or not this reflects a role for this organ in development of these cells, progenitors with the capacity to differentiate into ILC2 can be found in the thymus. These progenitors reside within a population which also has the capacity to generate $\mathrm{T}$ cells in response to apparently the same set of signals and we demonstrate that the strength of Notch signaling is an important determinant in deciding which fate is chosen. Apart from augmenting our understanding of the processes involved in the generation of ILC2, these findings also suggest possible avenues to generate ILC2 for reconstitution of this cell type in patients after stem cell transplantation or in patients suffering from immunodeficiencies.

\section{MATERIALS AND METHODS ISOLATION OF THYMIC HEMATOPOIETIC PROGENITORS}

Postnatal thymic (PNT) tissue specimens were obtained from children undergoing open heart surgery (LUMC, Leiden, The Netherlands); their use was approved by the AMC ethical committee in accordance with the declaration of Helsinki. Cell suspensions were prepared by mechanical disruption using the Stomacher 80 Biomaster (Seward). After overnight incubation at $4^{\circ} \mathrm{C}$, thymocytes were isolated from a Ficoll-Hypaque (Lymphoprep; Nycomed Pharma) density gradient. Single cell suspensions were enriched for $\mathrm{CD} 34^{+}$cells by MACS (Miltenyi Biotec), stained with fluorescently labeled antibodies and subsequently FACS sorted on a FACS 
Aria (BD Bioscience) as $\mathrm{CD} 34^{+} \mathrm{CD} 1 \mathrm{a}^{-} \mathrm{CD}^{-} \mathrm{CD}^{-} 6^{-} \mathrm{BDCA} 2^{-}$or $\mathrm{CD}_{4}{ }^{+} \mathrm{CD} \mathrm{a}^{+} \mathrm{CD}^{-} \mathrm{CD}^{-} 6^{-} \mathrm{BDCA}^{-}$, respectively (referred to in this study as $\mathrm{CD} 34^{+} \mathrm{CD}^{-}$and $\left.\mathrm{CD}^{-} 4^{+} \mathrm{CD} 1 \mathrm{a}^{+}\right)$. Purity of the sorted populations was $>99 \%$.

\section{FLOW CYTOMETRY}

Staining for expression of surface proteins was performed at $4^{\circ} \mathrm{C}$ for $20 \mathrm{~min}$. Distinction of live and dead cells was based on staining with 7-Aminoactinomycin D (7-AAD, eBiosciences) or fixable live/dead dyes (Invitrogen). Data were acquired on a LSR Fortessa flow cytometer (BD Bioscience) and analyzed using FlowJo software (TreeStar). Single cell suspensions were stained with antibodies directly labeled with Fluorescein Isothiocyanate (FITC), Phycoerythrin (PE), Phycoerythrin-Cyanine 5 (PE-Cy5), PE-Cy5.5, PE-Cy7, PerCP-Cy5.5, Allophycocyanin (APC)/Alexa Fluor 647, APC-Cy7, AF700 (all BD Bioscience, BioLegend, or MACS Miltenyi), Horizon V500 (HV500, BD Bioscience), Brilliant Violet 421 (BV421), BV711, and BV785 (all BioLegend). Antibodies specific for the following human antigens were used: CD1a, CD3, CD4, CD7, CD8, CD11c, CD14, CD19, CD25, CD34, CD45, CD56, CD94, CD117 (cKit), CD123, CD127 (IL7R $\alpha$ ), CD161, CD294 (CRTH2), CD303 (BDCA2), CD336 (Nkp44), CD278 (ICOS), TCR $\alpha \beta, \operatorname{TCR} \gamma \delta$, and Fc $\in$ R1. Anti-mouse CD90.1 (Thy1.1) -FITC, -PE, or -APC-eFluor 780 (eBioscience) were used to detect cells transduced with MSCV - IRES-Thy1.1 retroviruses.

\section{RETROVIRAL CONSTRUCTS}

The human NICD1-IRES-Thy1.1-MSCV construct has been described before (49). To generate the mER-NICD fusion, an $\mathrm{N}$-terminal mER domain was PCR amplified using the following primers: GATCAGGAATTCCACACCATGGGAGATCCACG AAATGAA and GATCAGGATATCCACCTTCCTCTTCTTCTTGG and cloned into the EcOR1 and EcORV sites of pBluescript (pBS) to create mER-pBS. Human NICD1 lacking a translation initiation signal was PCR amplified using these primers: ATCGGAGGTTCTCGCAAGCGCCGGCGGCAGCAT and GATCAGAAGCTTGAATTCTTACTTGAAGGCCTCCGGAATG and subsequently cloned into the EcORV and HindIII sites of mER-pBS. The mER-NICD1 fusion insert was then cloned into IRES-Thy1.1MSCV using BamH1 and Cla1.

\section{VIRUS PRODUCTION AND TRANSDUCTION}

For virus production, Phoenix GALV packaging cells were transiently transfected using FuGene HD (Promega). Virus containing supernatant was harvested $48 \mathrm{~h}$ after transfection, snap frozen on dry ice and stored at $-80^{\circ} \mathrm{C}$ until use. For transduction, cells were incubated with virus supernatant in plates coated with Retronectin $(30 \mu \mathrm{g} / \mathrm{ml}$, Takara Biomedicals $)$ for $6-8 \mathrm{~h}$ at $37^{\circ} \mathrm{C}$ the following day.

\section{IN VITRO DIFFERENTIATION OF THYMIC PROGENITORS}

Sorted thymic progenitors were cultured overnight in Yssel's medium containing 5\% normal human serum, SCF $(20 \mathrm{ng} / \mathrm{ml})$, and IL-7 (10 ng/ml, both PeproTech). OP9 cells were mitotically inactivated by irradiation with 30 Grey and seeded at a density of $5 \times 10^{3} / \mathrm{cm}^{2} 1$ day prior to initiation of co-cultures. After transduction, thymic progenitors were added to pre-seeded OP9 cells.
Co-cultures were performed in MEM $\alpha$ (Invitrogen) with FCS (20\%, FetalClone I, Hyclone) and IL-7 (5 ng/ml). In some cases, Flt3l ( $5 \mathrm{ng} / \mathrm{ml}$, PeproTech) was added to the medium. Cultures were refreshed every 3-4 days. Differentiation assays for ILCs were typically analyzed after 1 week, unless stated otherwise. Cells were harvested by forceful pipetting and passed through $70 \mu \mathrm{m}$ nylon mesh filters (Spectrum Labs). For longer culture periods, cells were transferred onto fresh stromal cells every week.

\section{QUANTITATIVE REAL-TIME PCR}

RNA was isolated using the NucleoSpin RNA II or NucleoSpin RNA XS kit (Macherey-Nagel) according to the manufacturer's instructions. cDNA synthesis was done using the High Capacity cDNA kit (Applied Biosystems). Quantitative Real-Time PCRs were performed in an iCycler instrument using IQ SYBR Green Supermix (both BioRad). For calculation of relative expression level of the genes of interest, the $\Delta \mathrm{Ct}$ method was used. The following primers were used: $A C T B$ ( $\beta$-Actin) (Gene ID: 60) Forward: CAC CAT TGG CAA TGA GCG GTT C; Reverse: AGG TCT TTG CGG ATG TCC ACG T; CRLF2 (TSLP-R) (Gene ID: 64109) Forward: GAG TGG CAG TCC AAA CAG GAA; Reverse: ACA TCC TCC ATA GCC TTC ACC; GATA3 (Gene ID: 2625) Forward: ACC ACA ACC ACA CTC TGG AGG A; Reverse: TCG GTT TCT GGT CTG GAT GCC T; IL1RL1 (ST2) (Gene ID: 9173) Forward: ATG TTC TGG ATT GAG GCC AC; Reverse: GAC TAC ATC TTC TCC AGG TAG CAT; IL-5 (Gene ID: 3567) Forward: AGC TGC CTA CGT GTA TGC CA; Reverse: CAG GAA CAG GAA TCC TCA GA; IL-13 (Gene ID: 3596) Forward: ATT GCT CTC ACT TGC CTT GG; Reverse: GTC AGG TTG ATG CTC CAT ACC; IL17RB (Gene ID: 55540) Forward: CCA ACA CAG CAC TAT CAT CG; Reverse: ATA TGG AGT CAG CTG CAC CG; PTGDR2 (CRTH2) (Gene ID: 11251) Forward: AAT CCT GTG CTC CCT CTG TG; Reverse: ATG TAG CGG ATG CTG GTG TT; RORA (Gene ID: 6095) Forward: ACA AGC AGC GGG AGG TGA TGT; Reverse: TGA GAG TCA AAG GCA CGG C.

\section{REPORTER GENE ASSAYS}

U2OS cells were transiently transfected using the FuGene HD transfection reagent (Promega). Cells were co-transfected with a NOTCH-responsive promoter and either NICD1-IRES-Thy1.1MSCV, mER-NICD1-Thy1.1-MSCV, or an empty vector control. To correct for differences in transfection efficiency, the pRL-CMV control vector was co-transfected, from which Renilla luciferase is expressed constitutively. Transfections were performed in triplicate. Where applicable, 4-Hydroxy-Tamoxifen (Sigma) was added after overnight incubation to induce nuclear translocation of mER-NICD1. Cells were lysed $48 \mathrm{~h}$ post transfection and luciferase activity was measured using the Dual Luciferase Reporter Assay System (Promega) on a Synergy HT microplate reader (Syntek). Two different Notch-responsive reporter constructs were used, which have been described previously (76).

\section{AUTHORS CONTRIBUTION}

Rebecca Gentek designed, performed, and analyzed experiments and wrote the manuscript. J. Marius Munneke and Christina Helbig performed and analyzed experiments. Bianca Blom, Mette D. Hazenberg, and Hergen Spits designed and analyzed experiments. 
Derk Amsen designed and analyzed experiments and wrote the manuscript.

\section{ACKNOWLEDGMENTS}

We thank Berend Hooibrink and Toni van Capel for maintaining the flow cytometry facility and instructions for the

\section{REFERENCES}

1. Spits $\mathrm{H}$, Artis D, Colonna M, Diefenbach A, Di Santo JP, Eberl G, et al. Innate lymphoid cells - a proposal for uniform nomenclature. Nat Rev Immunol (2013) 13:1-5. doi:10.1038/nri3365

2. Spits H, Di Santo JP. The expanding family of innate lymphoid cells: regulators and effectors of immunity and tissue remodeling. Nat Immunol (2011) 12:21-7. doi:10. 1038/ni.1962

3. Fuchs A, Vermi W, Lee JS, Lonardi S, Gilfillan S, Newberry RD, et al. Intraepithelial type 1 innate lymphoid cells are a unique subset of IL-12- and IL-15-responsive IFN$\gamma$-producing cells. Immunity (2013) 38:769-81. doi:10.1016/j.immuni. 2013.02.010

4. Bernink JH, Peters CP, Munneke $M$, te Velde AA, Meijer SL, Weijer $\mathrm{K}$, et al. Human type 1 innate lymphoid cells accumulate in inflamed mucosal tissues. Nat Immunol (2013) 14:221-9. doi:10. 1038/ni.2534

5. Klose CS, Kiss EA, Schwierzeck V, Ebert K, Hoyler T, d'Hargues Y, et al. A T-bet gradient controls the fate and function of CCR6ROR $\gamma \mathrm{t}+$ innate lymphoid cells. Nature (2013) 494:261-5. doi:10. 1038/nature11813

6. Moro K, Yamada T, Tanabe M, Takeuchi T, Ikawa T, Kawamoto $\mathrm{H}$, et al. Innate production of $\mathrm{T}(\mathrm{H}) 2$ cytokines by adipose tissue-associated c-Kit(+)Sca-1(+) lymphoid cells. Nature (2010) 463:540-4. doi: $10.1038 /$ nature 08636

7. Neill DR, Wong SH, Bellosi A, Flynn RJ, Daly M, Langford TK, et al. Nuocytes represent a new innate effector leukocyte that mediates type-2 immunity. Nature (2010) 464:1367-70. doi:10.1038/nature08900

8. Price AE, Liang HE, Sullivan BM, Reinhardt RL, Eisley CJ, Erle DJ, et al. Systemically dispersed innate IL13-expressing cells in type 2 immunity. Proc Natl Acad Sci U S A (2010) 107:11489-94. doi:10.1073/ pnas.1003988107

9. Mjösberg JM, Trifari S, Crellin NK, Peters CP, van Drunen CM, Piet B, et al. Human IL-25- and IL-33responsive type 2 innate lymphoid cells are defined by expression of
CRTH2 and CD161. Nat Immunol (2011) 12:1055-62. doi:10.1038/ni. 2104

10. Trifari S, Kaplan CD, Tran EH, Crellin NK, Spits H. Identification of a human helper $\mathrm{T}$ cell population that has abundant production of interleukin 22 and is distinct from $\mathrm{T}(\mathrm{H})-17, \mathrm{~T}(\mathrm{H}) 1$ and $\mathrm{T}(\mathrm{H}) 2$ cells. Nat Immunol (2009) 10:864-71. doi:10.1038/ni.1770

11. Crellin NK, Trifari S, Kaplan CD, Satoh-Takayama N, Di Santo JP, Spits H. Regulation of cytokine secretion in human CD127(+) LTilike innate lymphoid cells by tolllike receptor 2. Immunity (2010) 33:752-64. doi:10.1016/j.immuni. 2010.10.012

12. Takatori H, Kanno Y, Watford WT, Tato CM, Weiss G, Ivanov II, et al. Lymphoid tissue inducer-like cells are an innate source of IL-17 and IL-22. J Exp Med (2009) 206:35-41. doi:10.1084/jem.20072713

13. Ito $\mathrm{T}$, Wang $\mathrm{YH}$, Duramad O, Hori T, Delespesse GJ, Watanabe $\mathrm{N}$, et al. TSLP-activated dendritic cells induce an inflammatory $\mathrm{T}$ helper type 2 cell response through OX40 ligand. J Exp Med (2005) 202:1213-23. doi:10.1084/ jem.20051135

14. Chang YJ, Kim HY, Albacker LA, Baumgarth N, McKenzie AN, Smith DE, et al. Innate lymphoid cells mediate influenza-induced airway hyper-reactivity independently of adaptive immunity. Nat Immunol (2011) 12:631-8. doi:10.1038/ni. 2045

15. Monticelli LA, Sonnenberg GF, Abt MC, Alenghat T, Ziegler CG, Doering TA, et al. Innate lymphoid cells promote lung-tissue homeostasis after infection with influenza virus. Nat Immunol (2011) 12:1045-54. doi:10.1031/ni.2131

16. Klein Wolterink RG, Hendriks RW. Type 2 innate lymphocytes in allergic airway inflammation. Curr Allergy Asthma Rep (2013) 13(3):271-80. doi:10.1007/s11882013-0346-z

17. Barlow JL, Bellosi A, Hardman CS, Drynan LF, Wong SH, Cruickshank JP, et al. Innate IL-13-producing nuocytes arise during allergic lung inflammation and contribute to airways hyperreactivity. J Allergy Clin Immunol (2012) 129:e1-4. doi:10. 1016/j.jaci.2011.09.041

use of analyzers and sorters. Dr. Mark Hazekamp and the staff from the LUMC are acknowledged for providing human thymic tissue. This work was supported by grants from the AMC, The Landsteiner Foundation for Blood Research (LSBR) and Stichting Kinderen Kankervrij (KiKA) to Derk Amsen.

18. Kim HY, Chang YJ, Subramanian S, Lee $\mathrm{HH}$, Albacker LA, Matangkasombut $\mathrm{P}$, et al. Innate lymphoid cells responding to IL-33 mediate airway hyperreactivity independently of adaptive immunity. J Allergy Clin Immunol (2012) 129:e1-6. doi:10.1016/j.jaci.2011.10.036

19. Bartemes KR, Iijima K, Kobayashi T, Kephart GM, McKenzie AN, Kita H. IL-33-responsive lineageCD25+CD44hi lymphoid cells mediate innate type 2 immunity and allergic inflammation in the lungs. J Immunol (2011) 188:1503-13. doi:10.4049/jimmunol.1102832

20. Halim TY, Krauss RH, Sun AC, Takei F. Lung natural helper cells are a critical source of Th2 cell-type cytokines in protease allergen-induced airway inflammation. Immunity (2012) 36:451-63. doi:10.1016/j.immuni.2011.12.020

21. Spits H, Cupedo T. Innate lymphoid cells: emerging insights in development, lineage relationships, and function. Annu Rev Immunol (2011) 30:647-75. doi:10.1146/ annurev-immunol-020711-075053

22. Yang Q, Saenz SA, Zlotoff DA, Artis D, Bhandoola A. Cutting edge: natural helper cells derive from lymphoid progenitors. I Immunol (2011) 187:5505-9. doi:10.4049/ jimmunol.1102039

23. Wong SH, Walker JA, Jolin HE, Drynan LF, Hams E, Camelo A, et al. Transcription factor ROR $\alpha$ is critical for nuocyte development. Nat Immunol (2012) 13:229-36. doi:10. 1038/ni.2208

24. Six EM, Bonhomme D, Monteiro M, Beldjord K, Jurkowska M, CordierGarcia C, et al. A human postnatal lymphoid progenitor capable of circulating and seeding the thymus. $J$ Exp Med (2007) 204:3085-93. doi: 10.1084/jem.20071003

25. Spits H. Development of alphabeta $\mathrm{T}$ cells in the human thymus. Nat Rev Immunol (2002) 2:760-72. doi: $10.1038 /$ nri913

26. Hao QL, George AA, Zhu J, Barsky L, Zielinska E, Wang X, et al. Human intrathymic lineage commitment is marked by differential CD7 expression: identification of CD7lympho-myeloid thymic progenitors. Blood (2008) 111:1318-26. doi:10.1182/blood-2007-08106294
27. Taghon T, Van de Walle I, De Smet G, De Smedt M, Leclercq G, Vandekerckhove B, et al. Notch signaling is required for proliferation but not for differentiation at a welldefined beta-selection checkpoint during human T-cell development. Blood (2009) 113:3254-63. doi:10. 1182/blood-2008-07-168906

28. Vonarbourg C, Mortha A, Bui VL, Hernandez PP, Kiss EA, Hoyler T, et al. Regulated expression of nuclear receptor $\operatorname{ROR} \gamma t$ confers distinct functional fates to NK cell receptor-expressing ROR $\gamma \mathrm{t}(+)$ innate lymphocytes. Immunity (2010) 33:736-51. doi:10.1016/j.immuni.2010.10.017

29. Szabo SJ, Kim ST, Costa GL, Zhang X, Fathman CG, Glimcher LH. A novel transcription factor, T-bet, directs Thl lineage commitment. Cell (2000) 100:655-69. doi:10. 1016/S0092-8674(00)80702-3

30. Hoyler T, Connor CA, Kiss EA, Diefenbach A. T-bet and Gata3 in controlling type 1 and type 2 immunity mediated by innate lymphoid cells. Curr Opin Immunol (2013) 25:139-47. doi:10.1016/j.coi. 2013.02.007

31. Zheng W, Flavell RA. The transcription factor GATA-3 is necessary and sufficient for Th2 cytokine gene expression in CD4 $\mathrm{T}$ cells. Cell (1997) 89:587-96. doi:10.1016/ S0092-8674(00)80240-8

32. Hoyler T, Klose CS, Souabni A, Turqueti-neves A, Pfeifer D, Rawlins EL, et al. The transcription factor GATA-3 controls cell fate and maintenance of type 2 innate lymphoid cells. Immunity (2012) 37: 1-15. doi:10.1016/j.immuni.2012. 06.020

33. Mjösberg J, Bernink J, Golebski K, Karrich JJ, Peters CP, Blom B, et al. The transcription factor GATA3 is essential for the function of human type 2 innate lymphoid cells. Immunity (2012) 37:649-59. doi:10.1016/ j.immuni.2012.08.015

34. Klein Wolterink RG, Serafini N, van Nimwegen M, Vosshenrich CA, de Bruijn MJ, Fonseca Pereira D, et al. Essential, dose-dependent role for the transcription factor Gata3 in the development of IL-5+ and IL-13 + type 2 innate lymphoid cells. Proc Natl Acad Sci U S A (2013) 110(25):10240-5. doi:10. 1073/pnas. 1217158110 
35. Yang Q, Monticelli LA, Saenz SA, Chi AW, Sonnenberg GF, Tang J, et al. $\mathrm{T}$ cell factor 1 is required for group 2 innate lymphoid cell generation. Immunity (2013) 38:694-704. doi:10.1016/j.immuni. 2012.12.003

36. Bray SJ. Notch signalling: a simple pathway becomes complex. Nat Rev Mol Cell Biol (2006) 7:678-89. doi:10.1038/nrm2009

37. Radtke F, Macdonald HR, TacchiniCottier F. Regulation of innate and adaptive immunity by notch. Nat Rev Immunol (2013) 13:1-11. doi: 10.1038/nri3445

38. Cherrier M, Sawa S, Eberl G. Notch, Id 2 , and ROR $\gamma$ t sequentially orchestrate the fetal development of lymphoid tissue inducer cells. $J$ Exp Med (2012) 209:729-40. doi:10. 1084/jem.20111594

39. Lee JS, Cella M, McDonald KG, Garlanda C, Kennedy GD, Nukaya $\mathrm{M}$, et al. AHR drives the development of gut ILC22 cells and postnatal lymphoid tissues via pathways dependent on and independent of notch. Nat Immunol (2012) 13:144-51. doi:10.1038/ni. 2187

40. Rankin LC, Groom JR, Chopin M, Herold MJ, Walker JA, Mielke LA, et al. The transcription factor Tbet is essential for the development of NKp46+ innate lymphocytes via the notch pathway. Nat Immunol (2013) 14:389-95. doi:10.1038/ni. 2545

41. Halim TY, MacLaren A, Romanish MT, Gold MJ, McNagny KM, Takei F. Retinoic-acidreceptor-related orphan nuclear receptor alpha is required for natural helper cell development and allergic inflammation. Immunity (2012) 37:463-74. doi:10.1016/j.immuni.2012.06.012

42. Roediger B, Kyle R, Yip KH, Sumaria $\mathrm{N}$, Guy TV, Kim BS, et al. Cutaneous immunosurveillance and regulation of inflammation by group 2 innate lymphoid cells. Nat Immunol (2013) 14:564-73. doi:10.1038/ni. 2584

43. Blom B, Spits H. Development of human lymphoid cells. Annu Rev Immunol (2006) 24:287-320. doi:10.1146/annurev.immunol.24. 021605.090612

44. Zúñiga-Pflücker JC. T-cell development made simple. Nat Rev Immunol (2004) 4:67-72. doi:10. 1038/nri1257

45. Radtke F, Fasnacht N, Macdonald HR. Notch signaling in the immune system. Immunity (2010) 32:14-27. doi:10.1016/j.immuni.2010.01.004
46. Schmitt TM, Zúñiga-Pflücker JC. Induction of $\mathrm{T}$ cell development from hematopoietic progenitor cells by delta-like-1 in vitro. Immunity (2002) 17:749-56. doi:10.1016/ S1074-7613(02)00474-0

47. Van Coppernolle S, Verstichel G, Timmermans F, Velghe I, Vermijlen D, De Smedt M, et al. Functionally mature CD4 and CD8 TCRalphabeta cells are generated in OP9DL1 cultures from human CD34+ hematopoietic cells. J Immunol (2009) 183:4859-70. doi:10.4049/ jimmunol.0900714

48. Henriques CM, Rino J, Nibbs RJ, Graham GJ, Barata JT. IL-7 induces rapid clathrin-mediated internalization and JAK3-dependent degradation of IL-7Ralpha in T cells. Blood (2010) 115:3269-77. doi:10. 1182/blood-2009-10-246876

49. Amsen D, Blander JM, Lee GR, Tanigaki K, Honjo T, Flavell RA, et al. Instruction of distinct CD4 $\mathrm{T}$ helper cell fates by different notch ligands on antigen-presenting cells. Cell (2004) 117:515-26. doi: 10.1016/S0092-8674(04)00451-9

50. Amsen D, Antov A, Jankovic D, Sher A, Radtke F, Souabni A, et al. Direct regulation of Gata3 expression determines the $\mathrm{T}$ helper differentiation potential of notch. Immunity (2007) 27: 89-99. doi:10.1016/j.immuni.2007. 05.021

51. Fang TC, Yashiro-Ohtani Y, Del Bianco C, Knoblock DM, Blacklow SC, Pear WS. Notch directly regulates Gata3 expression during T helper 2 cell differentiation. Immunity (2007) 27:100-10. doi:10.1016/ j.immuni.2007.04.018

52. Van de Walle I, Waegemans E, De Medts J, De Smet G, De Smedt M, Snauwaert S, et al. Specific notch receptor-ligand interactions control human TCR- $\alpha \beta / \gamma \delta$ development by inducing differential notch signal strength. $J$ Exp Med (2013) 210:683-97. doi:10. 1084/jem. 20121798

53. Mazzone M, Selfors LM, Albeck J, Overholtzer M, Sale S, Carroll DL, et al. Dose-dependent induction of distinct phenotypic responses to notch pathway activation in mammary epithelial cells. Proc Natl Acad Sci U S A (2010) 107: 5012-7. doi:10.1073/pnas. 1000896107

54. Zhang Y, Riesterer C, Ayrall AM, Sablitzky F, Littlewood TD, Reth M. Inducible site-directed recombination in mouse embryonic stem cells. Nucleic Acids Res (1996) 24:543-8. doi:10.1093/nar/24.4.543
55. Brocard J, Warot X, Wendling $\mathrm{O}$, Messaddeq N, Vonesch JL, Chambon P, et al. Spatio-temporally controlled site-specific somatic mutagenesis in the mouse. Proc Natl Acad Sci U S A (1997) 94:14559-63. doi: 10.1073/pnas.94.26.14559

56. Jaisser F. Inducible gene expression and gene modification in transgenic mice. $J$ Am Soc Nephrol (2000) 11(Suppl 1): S95-100.

57. Holmes R, Zúñiga-Pflücker JC. The OP9-DL1 system: generation of Tlymphocytes from embryonic or hematopoietic stem cells in vitro. Cold Spring Harb Protoc (2009) 2009:db.rot5156. doi:10.1101/pdb. prot5156

58. Walker JA, McKenzie AN. Development and function of group 2 innate lymphoid cells. Curr Opin Immunol (2013) 25:1-8. doi:10. 1016/j.coi.2013.02.010

59. Zhang Z, Burnley P, Coder B, Su DM. Insights on FoxN1 biological significance and usages of the "nude" mouse in studies of T-lymphopoiesis. Int $\mathrm{J}$ Biol Sci (2012) 8:1156-67. doi:10.7150/ijbs. 5033

60. Weijer K. Intrathymic and extrathymic development of human plasmacytoid dendritic cell precursors in vivo. Blood (2002) 99:2752-9. doi:10.1182/blood.V99.8.2752

61. Romano R, Palamaro L, Fusco A, Iannace L, Maio S, Vigliano I, et al. From murine to human nude/SCID: the thymus, T-cell development and the missing link. Clin Dev Immuno (2012) 2012:467101. doi:10.1155/ 2012/467101

62. Rothenberg EV. Transcriptional drivers of the T-cell lineage program. Curr Opin Immunol (2012) 24:132-8. doi:10.1016/j.coi.2011.12.012

63. Schmitt TM, Zúñiga-Pflücker JC. T-cell development, doing it in a dish. Immunol Rev (2006) 209:95-102. doi:10.1111/j.01052896.2006.00353.x

64. Andersson ER, Sandberg R, Lendahl U. Notch signaling: simplicity in design, versatility in function. Development (2011) 138:3593-612. doi:10.1242/dev.063610

65. Van de Walle I, De Smet G, De Smedt M, Vandekerckhove B, Leclercq G, Plum J, et al. An early decrease in notch activation is required for human TCR-alphabeta lineage differentiation at the expense of TCR-gammadelta $\mathrm{T}$ cells. Blood (2009) 113:2988-98. doi:10.1182/ blood-2008-06-164871
66. Van de Walle I, De Smet G, Gärtner $M$, De Smedt $M$, Waegemans E, Vandekerckhove B, et al. Jagged2 acts as a Delta-like notch ligand during early hematopoietic cell fate decisions. Blood (2011) 117:4449-59. doi:10.1182/ blood-2010-06-290049

67. Radtke F, Wilson A, Mancini SJ, MacDonald HR. Notch regulation of lymphocyte development and function. Nat Immunol (2004) 5:247-53. doi:10.1038/ni1045

68. Yamaguchi E, Chiba S, Kumano K, Kunisato A, Takahashi T, Takahashi $\mathrm{T}$, et al. Expression of Notch ligands, Jagged1, 2 and Deltal in antigen presenting cells in mice. Immunol Lett (2002) 81:59-64. doi:10.1016/ S0165-2478(01)00326-1

69. Stanley P, Guidos CJ. Regulation of notch signaling during $\mathrm{T}$ - and B-cell development by O-fucose glycans. Immunol Rev (2009) 230:201-15. doi:10.1111/j. 1600-065X.2009.00791.x

70. Koch U, Yuan JS, Harper JA, Guidos CJ. Fine-tuning Notch1 activation by endocytosis and glycosylation. Semin Immunol (2003) 15(2):99-106. doi:10.1016/S10445323(03)00006-X

71. Takahama Y, Letterio JJ, Suzuki H, Farr AG, Singer A. Early progression of thymocytes along the CD4/CD8 developmental pathway is regulated by a subset of thymic epithelial cells expressing transforming growth factor beta. $J$ Exp Med (1994) 179:1495-506. doi:10. 1084/jem.179.5.1495

72. Colantonio AD, Epeldegui M, Jesiak $\mathrm{M}$, Jachimowski L, Blom B, Uittenbogaart $\mathrm{CH}$. IFN- $\alpha$ is constitutively expressed in the human thymus, but not in peripheral lymphoid organs. PLoS ONE (2011) 6:e24252. doi:10. 1371/journal.pone.0024252

73. Amsen D, Antov A, Flavell RA. The different faces of notch in $\mathrm{T}$ helper-cell differentiation. Nat Rev Immunol (2009) 9(2):116-24. doi: 10.1038/nri2488

74. Germar K, Dose M, Konstantinou T, Zhang J, Wang H, Lobry C, et al. Tcell factor 1 is a gatekeeper for T-cell specification in response to notch signaling. Proc Natl Acad Sci U S A (2011) 108:20060-5. doi:10.1073/ pnas. 1110230108

75. Li P, Burke S, Wang J, Chen X, Ortiz M, Lee SC, et al. Reprogramming of $\mathrm{T}$ cells to natural killerlike cells upon Bcl11b deletion. Science (2010) 329:85-9. doi:10.1126/ science. 1188063

76. Nam Y, Sliz P, Pear WS, Aster JC Blacklow SC. Cooperative assembly 
of higher-order notch complexes functions as a switch to induce transcription. Proc Natl Acad Sci U S A (2007) 104:2103-8. doi:10.1073/ pnas.0611092104

Conflict of Interest Statement: The authors declare that the research was conducted in the absence of any commercial or financial relationships that could be construed as a potential conflict of interest.

Received: 31 July 2013; accepted: 02 October 2013; published online: 22 October 2013.

Citation: Gentek R, Munneke JM, Helbig C, Blom B, Hazenberg MD, Spits $H$ and Amsen D (2013) Modulation of signal strength switches Notch from an inducer of $T$ cells to an inducer of ILC2. Front. Immunol. 4:334. doi: 10.3389/fimmu.2013.00334

This article was submitted to Molecular Innate Immunity, a section of the journal Frontiers in Immunology.

Copyright (c) 2013 Gentek, Munneke, Helbig, Blom, Hazenberg, Spits and Amsen. This is an open-access article distributed under the terms of the Creative Commons Attribution License (CC $B Y)$. The use, distribution or reproduction in other forums is permitted, provided the original author(s) or licensor are credited and that the original publication in this journal is cited, in accordance with accepted academic practice. No use, distribution or reproduction is permitted which does not comply with these terms. 